\title{
Pengembangan Modul Pembelajaran Berbasis Blended Learning Mata Pelajaran Rancang Bangun Jaringan
}

\author{
Panyahuti, Kasman Rukun, Waskito \\ Universitas Negeri Padang, Padang \\ Email: p.matondang@gmail.com
}

\begin{abstract}
This research is written based on the learning difficulties during industrial internship activities. This research is to produce a learning module for students who implement Prakerin with the Blended Learning model. To know the validity of modules, the effectiveness, and effectiveness of the developed learning modules. The method used is Research and Development (R \& D) by using the FOUR D development model that is the definition, design, development, and deployment. The research design used for the trial module is quasi-experiment with a time series model. The module made is valid by the material expert with the average of all eligibility is $80.38 \%$, included in the "Excellent" category. The modular practicality analysis is $81.41 \%$, included in the "Practical" category. Module effectiveness analysis, included in the "Good" category. From both data analysis results done, it can be stated that the module is effective in improving learning outcomes.
\end{abstract}

Keywords: Blended Learning-Based Learning, Industrial Work Practices, Learning

\section{Module}

\section{PENDAHULUAN}

Pelaksanaan praktik kerja industri yang dilaksanakan di SMK selama minimal tiga bulan, telah menghilangkan pembelajaran secara manual dikelas, hal ini menyebabkan target pencapaian materi pembelajaran yang harus diajarkan oleh guru menjadi terhambat. Sehingga beberapa topi-topik pembelajaran tidak bisa disampaikan atau diajarkan kepada siswa (Pamekas \& Dwihartanti, 2016). Dengan adanya permasalahan tersebut maka diperlukan aktivitas pembelajaran tambahan yang dilaksanakan oleh guru mata pelajaran, ketika siswa melaksanakan Prakerin, namun kegiatan pembelajaran tersebut tidak mengganggu program Prakerin yang berjalan. Aktivitas pembelajaran yang berlangsung secara mandiri harus bisa dikontrol oleh guru (Susana, 2016).

Pembelajaran tambahan yang dapat dilakukan saat siswa Prakerin adalah pembelajaran yang dilakukan secara online. Blended learning menjadi salah satu pilihan yang dapat dilaksanakan sebagai solusi untuk permasalahan siswa peserta Prakerin (Rizkiyah, 2015). Menurut Surjono (2013) blended learning adalah pembelajaran yang menggabungkan semua bentuk pembelajaran misalnya online, live, maupun tatap muka (konvensional). Sebelum siswa melaksanakan Prakerin guru melakukan pembelajaran tatap 
muka di kelas untuk memberikan arahanarahan apa yang harus dilakukan siswa, bagaimana melakukannya dan semua syaratsyarat pembelajaran. Selama siswa melaksanakan Prakerin, guru menyampaikan materi dan siswa masih bisa belajar menggunakan media online yang ada. Media online dapat berupa e-learning, email, media sosial, dan lain sebagainya.

Tujuan penelitian ini adalah untuk menghasilkan sebuah modul pembelajaran Rancang Bangun Jaringan dengan model pembelajaran berbasis blended learning, dan untuk mengetahui validitas, praktikalitas dan efektifitas modul yang dikembangkan tersebut.

\section{METODE}

Penelitian ini adalah penelitian pengembangan (development research) dengan model pengembangan Four-D Model ini terdirid ari 4 tahap pengembangan yaitu Define, Design, Develop, dan Disseminate. Pengembangan yang dilakukan menghasilkan sebuah modul pembelajaran Rancang Bangun Jaringan untuk digunakan siswa SMK Negeri 1 Lahat, pada waktu pelaksanaan Praktik Kerja Industri. Modul dan tugas-tugas didistribusikan melalui e-Learning diakses pada halaman lms.smkn1lahat.sch.id. Subjek penelitian kels XI Teknik Komputer dan Jaringan dengan jumlah siswa 36 orang.

Teknik pengumpulan data dilaksanakan dengan menggunakan angket dan tes hasil belajar. Instrumen penelitian yang digunakan adalah lembar validasi modul oleh ahli materi dan ahli media, lembar angket untuk siswa dan soal-soal penilaian hasil belajar.

Modul yang telah dibuat diuji cobakan kepada siswa kelas XI TKJ SMK Negeri 1 Lahat. Materi pelajaran yang akan dicobakan a) Internet dan pemanfaatannya; b) Perencanaan pemutakhiran jaringan c) Perencanaan Struktur Pengalamatan.

Desain penelitian menggunakan desain Quasi Eksperimen denganTime Series Design. Pada penelitian jenis ini kelompok yang diteliti tidak bisa dipilih secara random, tidak terdapat kelompok kontrol. Tetapi hanya satu kelompok yang diukur dan diamati gejala-gejala yang muncul setelah diberi perlakuan/posttes (Sugiyono, 2015). Desain penelitiannya adalah sebagai berikut:

Tabel 1.

Times Series Designs

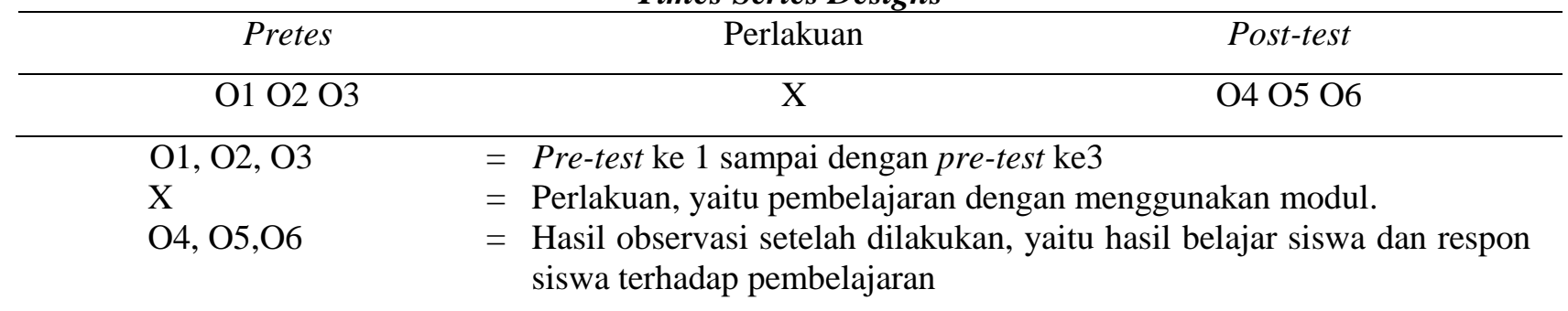

Analisis validasi modul pembelajaran dilakukan, dengan mencari rata-rata tiap kategori dan rata-rata tiap aspek dalam lembar validasi, hingga ahirnya didapatkan rata-rata total penilaian validator terhadap modul. Hasil validasi para ahi dibandingkan dengan tabel tolok ukur kategori persentase.

Tabel 2.

Kategori Persentase

\begin{tabular}{cc}
\hline Persentase & Kategori \\
\hline $80,00-100.00$ & Sangat baik \\
$60,00-79,99$ & Baik \\
$40,00-59,99$ & Cukup \\
$00,00-39,99$ & Kurang \\
\hline
\end{tabular}

Sumber: Jakni (2016)

$$
\text { Analisis Praktikalitas dilakukan }
$$
dengan mengukur respon siswa terhadap penggunaan modul dalam pembelajaran, penilaian ideal sebagai berikut:

$$
\text { Prs }=\frac{A}{B} X 100 \%
$$

Prs $=$ Persentase respon siswa

A $=$ Total Jumlah skor jawaban siswa

$\mathrm{B}=$ skor maksimal 
Tabel 3.

Kriteria Kategori Praktikalitas

\begin{tabular}{cc}
\hline Tingkat Pencapaian \% & Kategori \\
\hline $90-100$ & Sangat Praktis \\
$80-89$ & Praktis \\
$65-79$ & Cukup Praktis \\
$55-64$ & Kurang Praktis \\
\hline $0-54$ & Tidak praktis \\
\hline Sumber: Adriani \& Silitonga (2017)
\end{tabular}

Efektifitas modul dilakukan dengan dua cara yaitu: a) menganisis hasil belajar siswa dan b) Uji t, dilakukan dengan menjumlahkan nilai post-test $(\mathrm{O} 4+\mathrm{O} 5+06)$ dan nilai pre-test $(\mathrm{O} 1+\mathrm{O} 2+\mathrm{O} 3)$, kemudian menguji perbedaan keduanya.

\section{HASIL PENELITIAN DAN PEMBAHASAN}

\section{Hasil Penelitian}

Hasil penelitian ini menghasilkan sebuah modul pembelajaran dengan judul "Internet dan Perencanaan Pengembangan Jaringan" yang telah diuji coba, kemudian diuji validitas, praktikalitas serta efektivitasnya. Untuk menguji validitas diminta bantuan para ahliya itu ahli materi dua orang dan ahli media 1 orang. Instrumen validasi diambil dari BSNP dengan mangadopsi instrument Standar Nasional BukuTeks Pelajaran tahun 2013.

\section{Pembahasan}

Modul yang dibuat didistribusikan
melalui
http://www.lms.smkn1lahat.sch.id, dengan format .PDF dan EPUB. Untuk memudahkan komunikasi antara guru dan siswa serta untuk mengontrol keterlaksanaan pembelajaran dibuat sebuah group pada aplikasi Whatsapp yang berbasis Android atau IOS.

Modul yang dibuat dinyatakan valid oleh ahli materi dengan skor penilaian keseluruhan rata-rata penilaian semua ahli memperoleh kelayakan yaitu, kelayakan isi $82,50 \%$, kelayakan penyajian $81,73 \%$ kelayakan kebahasaan $82,29 \%$ dan kelayakan kegrafikan $75 \%$, rata-rata semua kelayakan adalah 80,38\% termasuk dalam kategori "Sangat Baik". diperoleh:

$$
\begin{aligned}
\text { Prs } & =\frac{2930,83}{4320} ; 100 \% \\
\text { Prs } & =81,41 \%
\end{aligned}
$$

Total persentase jawaban siswa adalah $81.41 \%$ termasuk dalam kategori "Praktis", modul bisa disimpulkan praktis untuk digunakan oleh siswa.

Analisis efektifitas modul dilakukan dengan dua cara yaitu analisis ketuntasan belajar dan uji perbedaan antara pre-test dengan post-test menggunakan uji t. Hasil yang diperoleh adalah rata-rata ketuntasan siswa dalam proses pembelajaran menggunakan modul tersebut untuk 3 kali post-test yang dilaksanakan, diperoleh ketuntasan klasikal $61 \%$ termasuk kategori "Baik".

Untuk uji t, diperoleh korelasi antara variabel pre-test dengan post-test ada sebesar 0,466 dengan taraf signifikan sebesar 0,04. Karena taraf signifikan $0,04<0,05$ maka dapat dinyatakan bahwa ada hubungan hasil belajar antara sebelum diberikan modul dengan sesudah diberikan modul. Dari gambar 4.6 tabel paired samples test diperoleh $\mathrm{t}=14,608$ pada df 35 . Karena $t$ hitung $>\mathrm{t}$ tabel yaitu: $14,608>2,43772$ atau taraf signifikan sig< 0,01 yaitu $0,000<0,01$, maka terdapat perbedaan yang signifikan sebelum diberi modul dengan setelah diberi modul pembelajaran. Dari kedua hasil analsis data yang dilakukan dapat dinyatakan bahwa modul "Internet dan Perencanaan Pengembangan Jaringan" efektif dalam meningkatkan hasil belajar.

\section{SIMPULAN}

Penelitian ini menghasilkan sebuah produk yaitu modul pembelajaran Rancang Bangun Jaringan untuk siswa XI TKJ dengan judul "Internet dan Perencanaan Pengembangan Jaringan". Modul pembelajaran yang dibuat telah diuji coba, kemudian diuji validitas, praktikalitas serta efektivitasnya. Untuk menguji validitas diminta bantuan para ahli yaitu ahli materi dua orang dan ahli media 1 orang. Instrumen validasi diambil dari BSNP dengan mangadopsi instrumen Standar Nasional Buku Teks Pelajaran tahun 2013.

Modul yang dibuat dinyatakan valid oleh ahli materi dengan skor penilaian 
keseluruhan rata-rata penilaian semua ahli memperoleh kelayakan yaitu, kelayakan isi $82,50 \%$, kelayakan penyajian $81,73 \%$ kelayakan kebahasaan 82,29\% dan kelayakan kegrafikan $75 \%$, rata-rata semua kelayakan adalah 80,38\% termasuk dalam kategori "Sangat Baik".

Analisis praktikalitas modul dilakukan dengan memberikan angket kepada siswa. Total persentase jawaban siswa adalah $81.41 \%$ termasuk dalam kategori "Praktis", modul bisa disimpulkan praktis untuk digunakan oleh siswa.

Analisis efektifitas modul dilakukan dengan dua cara yaitu analisis ketuntasan belajar dan uji perbedaan antara pre-test dengan post-test menggunakan uji t. Berdasarkan ketuntasan belajar siswa untuk 3 kali post-test yang dilaksanakan, ketuntasan klasikal 61\% termasuk kategori "Baik".

Berdasaran kesimpulan tersebut pembelajaran menggunakan modul berbasis blended learning untuk siswa yang sedang melaksanakan Prakrin adalah salah satu solusi untuk tetap melaksanakan pembelajaran selama melaksanakan kegiatan Prakerin.

\section{DAFTAR PUSTAKA}

Adriani, N., \& Silitonga, F. S. (2017). Pengembangan Modul Ajar Kimia Unsur Berbasis Inkuiri Terimbing untuk Mahasiswa Pendidikan Kimia. In Prosiding Seminar Nasional Kimia UNY
2017 Sinergi Penelitian dan Pembelajaran untuk Mendukung Pengembangan Literasi Kimia pada Era Global (pp. 109-114). Yogyakarta.

Pamekas, R., \& Dwihartanti, M. (2016). Pelaksanaan Praktik Kerja Industri Peserta Didik Kelas XI Kompetensi Keahlian Administrasi Perkantoran SMK BOPKRI 1 Yogyakarta. Jurnal Pendidikan Administrasi Perkantoran, 5(1), 155-163.

Rizkiyah, A. (2015). Penerapan Blended Learning untuk Meningkatkan Hasil Belajar Siswa pada Mata Pelajaran Ilmu Bangunan di Kelas X TGB SMK Negeri 7 Surabaya. Jurnal Kajian Pendidikan Teknik Bangunan, 1(1), 40-49.

Sugiyono. (2015). Metode Penelitian \& Pengembangan Research and Development. Bandung: Alfa Beta.

Surjono, H. D. (2013). Membangun Course eLearning Berbasis Moodle. Yogyakarta: UNY.

Susana, N. (2016). Pengelolaan Praktik Kerja Industri. Manajer Pendidikan, 10(6), 579-587. 